\title{
Dynamics of number of the pea aphid (Acyrthosiphon pisum Harris, 1776) on the selected varieties of pea and faba bean
}

\section{Dynamika liczebności mszycy grochowej (Acyrthosiphon pisum Harris, 1776) na wybranych odmianach grochu i bobiku}

\author{
Przemysław Strażyński*, Maria Ruszkowska, Adam Bartkowski, Arleta Krówczyńska
}

\begin{abstract}
Summary
The aim of the study was to assess the dynamics of number of the pea aphid on selected varieties of pea and faba bean. The experiment was conducted in a climate chamber in the Institute of Plant Protection - National Research Institute in Poznań, under controlled conditions (constant temperature, humidity and photoperiod), with ten replications. Five varieties of peas: Muza, Milwa, Model, Mentor, Mecenas, and two varieties of faba bean: Nadwiślański and Amulet were tested. Observations of the number of aphids on each plant were conducted at regular intervals. The average fertility of aphids was defined for each variety. The results of the experiment showed that the pea plants were more inhabited by the pea aphid than faba bean varieties. Among the tested pea varieties, Acyrthosiphon pisum developed the best on the varieties Mecenas and Milwa, characterized by the highest protein level. As far as faba bean varieties are considered, low-tannin variety Amulet was a better host plant for the pea aphid.
\end{abstract}

Key words: pea; faba bean; varieties; pea aphid; Acyrthosiphon pisum; dynamics of number

\section{Streszczenie}

Celem badań była ocena dynamiki liczebności mszycy grochowej na wybranych odmianach grochu i bobiku. Doświadczenie prowadzono w kabinie klimatycznej w Instytucie Ochrony Roślin - Państwowym Instytucie Badawczym w Poznaniu, w kontrolowanych warunkach (stała temperatura, wilgotność, fotoperiod), w dziesięciu powtórzeniach. Testowano pięć odmian grochu: Muza, Milwa, Model, Mentor, Mecenas oraz dwie odmiany bobiku - Nadwiślański i Amulet. Obserwacje liczebności mszyc na poszczególnych roślinach prowadzono $w$ stałych odstępach czasu. Dla każdej z odmian określono także średnią płodność mszyc. W wyniku doświadczenia wykazano, że rośliny grochu były chętniej zasiedlane przez mszycę grochową niż odmiany bobiku. Spośród testowanych odmian grochu, Acyrthosiphon pisum najlepiej rozwijała się na odmianach Mecenas i Milwa, o najwyższej spośród badanych odmian zawartości białka. Z obydwu testowanych odmian bobiku, niskotaninowa odmiana Amulet była lepszym gospodarzem dla mszycy grochowej.

Słowa kluczowe: groch; bobik; odmiany; mszyca grochowa; Acyrthosiphon pisum; dynamika liczebności

Instytut Ochrony Roślin - Państwowy Instytut Badawczy

Zakład Entomologii

Władysława Węgorka 20, 60-318 Poznań

*corresponding author: P.Strazynski@iorpib.poznan.pl 


\section{Wstęp / Introduction}

Mszyce (Aphidoidea) zaliczane są do jednych z ważniejszych gospodarczo szkodników roślin uprawnych, w tym bobowatych (Mrówczyński i wsp. 2006). Mszyca grochowa (Acyrthosiphon pisum Harris, 1776) jest gatunkiem jednodomnym, oligofagicznym, zasiedlającym praktycznie wszystkie gatunki z tej rodziny (Szelegiewicz 1968; Holman 2009). W przypadku masowego pojawu mszyc, na skutek żerowania dochodzi do osłabienia, obumarcia fragmentów lub całych roślin. Osłabione rośliny są z kolei bardziej podatne na porażenie przez patogeny chorobotwórcze. Istotny jest także aspekt pośredniej szkodliwości A. pisum, czyli przenoszenia wirusów. Gatunek ten notowany jest między innymi jako wektor wirusa żółtej mozaiki fasoli (BYMV - Bean Yellow Mosaic Virus) (Sohi i Swenson 1964; Hodges i McLean 1969).

$\mathrm{Na}$ zasiedlenie danej rośliny przez mszycę wpływa wiele czynników, a przede wszystkim: barwa, smak i zawartość aminokwasów, zapach czy fenologia rośliny (Montllor i Tjallingii 1989; Montllor 1991; Leszczyński 1996; Caillauda i Via 2000). Podjęcie żerowania właściwego (tj. dotarcia do floemu) i rozwoju na danym gatunku rośliny bądź odmiany poprzedza rozpoznanie, między innymi próbna penetracja tkanek (Goławska i wsp. 2007). Również czynniki abiotyczne, głównie temperatura i wilgotność mają istotny wpływ na rozwój i liczebność mszycy grochowej (Kilian i Nielson 1971; Wójtowska 1990).

Celem badań było prześledzenie dynamiki liczebności A. pisum na wybranych odmianach grochu i bobiku.

\section{Materiały i metody / Materials and methods}

Doświadczenie prowadzono w kabinie klimatycznej w Instytucie Ochrony Roślin - Państwowym Instytucie Badawczym w Poznaniu, w stałych warunkach kontrolowanych (temperatura $19^{\circ} \mathrm{C}$, wilgotność $70 \%$, naświetlenie - 14 godzin światła, 10 godzin ciemności). Do testów wybrano dwie odmiany grochu pastewnego: Milwa zawartość białka 23,6\% suchej masy (s.m.), Model - zawartość białka 23,2\% s.m. i trzy ogólnoużytkowe, o różnej zawartości białka ogólnego w suchej masie: Mecenas 23,7\% s.m., Mentor - 22,7\% s.m. i Muza - 23,2\% s.m., a także dwie odmiany bobiku: niskotaninową $(0,03 \mathrm{mg} / \mathrm{g}$ s.m.) - Amulet i tradycyjną, o wysokiej zawartości tanin (0,5 mg/g s.m.) - Nadwiślański. W izolowanych pojemnikach znajdywały się po trzy rośliny każdej z odmian w fazie trzeciego liścia (BBCH 13), które stanowiły jedno powtórzenie. Na każdą z roślin nanoszono po 1 mszycy A. pisum w stadium L4, biotyp zielony, pozyskaną z hodowli na grochu odmiany Milwa. Obserwacje zmian liczebności mszyc (wszystkich stadiów rozwojowych) prowadzono w stałych odstępach czasu, tj. co 3, 5, 7, 10 i 14 dni, natomiast samych larw w stadium L1 co 5, 7, 10 i 14 dni. Na każdej z odmian określono średnią płodność całkowitą mszyc. Doświadczenie prowadzono w dziesięciu powtórzeniach. Liczbę osobników na poszczególnych obiektach doświadczalnych porównano statystycznie przy użyciu programu STATISTICA v. 10, na danych przek- ształconych według przekształcenia pierwiastkowego uniwersalnego Freemana-Tukeya. Wykonano analizę wariancji i zastosowano test Tukeya przy poziomie istotności $\alpha=0,05$.

\section{Wyniki i dyskusja / Results and discussion}

Doświadczenia przeprowadzone w kontrolowanych warunkach i w dziesięciu powtórzeniach wykazały różną dynamikę liczebności mszycy grochowej na poszczególnych odmianach grochu i bobiku. Na wszystkich odmianach obserwowano stopniowy wzrost liczebności mszyc przez cały okres trwania doświadczenia. Na grochu w trzecim dniu obserwacji największą liczebność mszyc notowano na odmianie Mecenas, z kolei począwszy od piątego dnia również na odmianie Milwa (tab. 1). A. pisum gorzej rozwijała się na odmianach Muza i Model, na których liczebność mszyc była statystycznie różna w stosunku do pozostałych odmian, zwłaszcza w siódmym i dziesiątym dniu trwania doświadczenia. Po czternastu dniach (koniec obserwacji) nie stwierdzono istotnych różnic liczebności mszyc na odmianach: Muza, Mentor, Mecenas i Milwa.

Obydwie odmiany bobiku były gorszymi żywicielami dla $A$. pisum niż rośliny grochu. Testowane odmiany bobiku różniły się również między sobą pod względem liczebności żerujących mszyc. Istotne różnice w liczebności mszyc na roślinach bobiku stwierdzono od piątego dnia obserwacji. Na odmianie Amulet notowano pod koniec doświadczenia średnio 43,2 mszyce, podczas gdy na odmianie Nadwiślański tylko 16,8 (tab. 1). Badane odmiany bobiku różniły się między sobą zawartością tanin. Wcześniejsze badania nad zasiedlaniem bobiku przez szkodniki wykazały, że mszyce najliczniej zasiedlały odmiany niskotaninowe (Ropek i Kulig 2009, 2011). Również Kolasińska i Wiewióra (2002) przypisują taninom rolę obronną przed agrofagami. Stąd prawdopodobnie wynika fakt większej liczebności $A$. pisum na badanej odmianie Amulet.

W doświadczeniu na grochu stwierdzono zróżnicowane tempo reprodukcji na poszczególnych odmianach w piątym i siódmym dniu obserwacji (tab. 2). W piątym dniu minimalną średnią płodność $A$. pisum na grochu zanotowano na odmianie Muza (6,2 szt.), natomiast maksymalną na odmianach Mecenas i Milwa ( 9,1 szt.). W siódmym dniu doświadczenia minimalną płodność stwierdzono na odmianie Model (10,3 szt.), z kolei maksimum na odmianie Mecenas (12,7 szt.). W dziesiątym i czternastym dniu nie stwierdzono różnic płodności mszyc na testowanych odmianach grochu.

Na bobiku notowano zmienną płodność mszyc - w kolejnych dniach wartości te różniły się statystycznie na obydwu odmianach (tab. 2). W piątym dniu obserwacji minimum płodności odnotowano na odmianie Nadwiślański (0,4 szt.), a maksymalną liczbę na odmianie Amulet (2,5 szt.). Podobne różnice wystąpiły po siedmiu, dziesięciu i czternastu dniach. W czternastym dniu doświadczenia na odmianie Amulet płodność wyniosła 12,3 szt. i nie różniła się ona statystycznie w porównaniu do testowanych odmian grochu. 
Tabela 1. Dynamika liczebności A. pisum na odmianach grochu (G) i bobiku (B) w warunkach kontrolowanych (średnie wartości z 10 powtórzeń w sztukach)

Table 1. The dynamics of the number of $A$. pisum on varieties of pea $(\mathrm{G})$ and faba bean (B) under controlled conditions (average values of 10 replications in pieces)

\begin{tabular}{|c|c|c|c|c|c|}
\hline \multirow{2}{*}{$\begin{array}{c}\text { Odmiana } \\
\text { Variety }\end{array}$} & \multicolumn{5}{|c|}{ Dni - Days } \\
\hline & 3 & 5 & 7 & 10 & 14 \\
\hline G - Muza & $3,1 \mathrm{~b}$ & $9,2 \mathrm{~b}$ & $21,4 \mathrm{ab}$ & $36,7 \mathrm{ab}$ & $51,5 \mathrm{a}$ \\
\hline G-Model & $3,0 \mathrm{~b}$ & $9,4 \mathrm{~b}$ & $20,0 \mathrm{abc}$ & $35,6 \mathrm{ab}$ & $49,8 \mathrm{ab}$ \\
\hline $\mathrm{G}-$ Mentor & $3,0 \mathrm{~b}$ & $9,6 \mathrm{~b}$ & $22,3 \mathrm{a}$ & $37,7 \mathrm{a}$ & $51,8 \mathrm{a}$ \\
\hline $\mathrm{G}$ - Mecenas & $3,8 \mathrm{a}$ & $11,9 \mathrm{a}$ & $23,7 \mathrm{a}$ & $39,2 \mathrm{a}$ & $52,0 \mathrm{a}$ \\
\hline G-Milwa & $3,1 \mathrm{~b}$ & $12,1 \mathrm{a}$ & $23,9 \mathrm{a}$ & $39,3 \mathrm{a}$ & $52,1 \mathrm{a}$ \\
\hline $\mathrm{B}-$ Amulet & $3,0 \mathrm{~b}$ & $5,5 \mathrm{c}$ & $13,2 \mathrm{bc}$ & $25,4 \mathrm{bc}$ & $43,2 \mathrm{bc}$ \\
\hline B - Nadwiślański & $2,8 \mathrm{~b}$ & $3,0 \mathrm{~d}$ & $4,9 \mathrm{c}$ & $10,6 \mathrm{c}$ & $16,8 \mathrm{c}$ \\
\hline
\end{tabular}

Wartości w kolumnach oznaczone tą samą literą nie różnią się istotnie - Values in columns marked with the same letters do not differ significantly

Tabela 2. Średnia płodność A. pisum na testowanych odmianach grochu (G) i bobiku (B) w warunkach kontrolowanych (średnie wartości w sztukach z 10 powtórzeń)

Table 2. Average fertility of A. pisum on pea $(\mathrm{G})$ and faba bean (B) tested under controlled conditions (average values in pieces from 10 replications)

\begin{tabular}{l|c|c|c|c}
\hline \multirow{2}{*}{$\begin{array}{c}\text { Odmiana } \\
\text { Variety }\end{array}$} & \multicolumn{4}{c}{ Dni-Days } \\
\cline { 2 - 5 } & 5 & 7 & 10 & 14 \\
\hline $\mathrm{G}-$ Muza & $6,2 \mathrm{ab}$ & $12,3 \mathrm{a}$ & $15,1 \mathrm{a}$ & $13,8 \mathrm{a}$ \\
\hline $\mathrm{G}-$ Model & $6,4 \mathrm{ab}$ & $10,3 \mathrm{ab}$ & $15,4 \mathrm{a}$ & $14,1 \mathrm{a}$ \\
\hline $\mathrm{G}-$ Mentor & $6,6 \mathrm{ab}$ & $11,8 \mathrm{ab}$ & $15,9 \mathrm{a}$ & $14,1 \mathrm{a}$ \\
\hline $\mathrm{G}-$ Mecenas & $9,1 \mathrm{a}$ & $12,7 \mathrm{a}$ & $15,2 \mathrm{a}$ & $14,2 \mathrm{a}$ \\
\hline $\mathrm{G}-$ Milwa & $9,1 \mathrm{a}$ & $11,8 \mathrm{ab}$ & $11,3 \mathrm{~b}$ & $12,3 \mathrm{a}$ \\
\hline $\mathrm{B}-$ Amulet & $2,5 \mathrm{bc}$ & $7,7 \mathrm{bc}$ & $5,7 \mathrm{c}$ & $6,2 \mathrm{~b}$ \\
\hline $\mathrm{B}-$ Nadwiślański & $0,4 \mathrm{c}$ & $1,9 \mathrm{c}$ & \multicolumn{2}{c}{} \\
\hline
\end{tabular}

Wartości w kolumnach oznaczone tą samą literą nie różnią się istotnie - Values in columns marked with the same letters do not differ significantly

Badania wskaźników demograficznych A. pisum rejestrowanych na odmianach grochu, prowadzone przez Słomkę i Kordan (2008), także wykazały zróżnicowanie średniej płodności mszyc. Autorzy tłumaczyli ten fakt ilościowym i jakościowym składem soku floemowego roślin, głównie zawartością aminokwasów. Również badania na odmianach bobu (Cichocka i wsp. 2002) wykazały większą podatność na mszyce odmian o wyższej zawartości aminokwasów endo- i egzogennych.

Spadek tempa rozwoju na grochu mógł być spowodowany wyleganiem roślin $\mathrm{w}$ końcowej fazie doświadczenia, zagęszczeniem się populacji lub też obniżeniem wartości pokarmowej zasiedlonych roślin. Węgorek (1969) w swoich badaniach wykazał, że biotyp zielony pochodzący z grochu po dwóch tygodniach tworzył liczniejsze kolonie na bobie niż na grochu, uznając przy tym groch za mało atrakcyjną roślinę dla biotypów $A$. pisum żerujących wcześniej na innych roślinach żywicielskich. Podkreślił również wyraźną specjalizację mszycy grochowej, wyrażającą się różną tolerancją na zmianę żywiciela.

Spośród wszystkich gatunków roślin bobowatych (Fabaceae) A. pisum najchętniej zasiedla groch i bób (Słomka i Kordan 2010). Badania zachowania mszycy grochowej podczas żerowania metodą EPG (Electrical Penetration Graph) wykazały, że groch i bobik są znacznie lepiej akceptowanymi roślinami żywicielskimi dla tego gatunku w porównaniu z fasolą, koniczyną i lucerną (Goławska i wsp. 2007). W innych badaniach Goławskiej (2010) ustalono podobnie, że parametry demograficzne populacji A. pisum, jak wrodzone tempo wzrostu populacji, tempo reprodukcji netto, tempo zwielokrotnienia liczebności populacji posiadały znacznie wyższe wartości dla mszyc żerujących na grochu i bobiku. A. pisum jest notowana jako ważny szkodnik na plantacjach bobiku, choć pojawia się na nim stosunkowo późno i w rozproszonych koloniach (Sądej i Nietupski 2000).

\section{Wnioski / Conclusions}

1. Groch jest lepszą rośliną żywicielska dla $A$. pisum w porównaniu $\mathrm{z}$ bobikiem.

2. Spośród testowanych odmian grochu A. pisum najlepiej rozwijała się na odmianach Mecenas i Milwa, o najwyższej spośród badanych odmian zawartości białka.

3. Z obydwu testowanych odmian bobiku, niskotaninowa odmiana Amulet była lepszym gospodarzem dla mszycy grochowej. 


\section{Literatura / References}

Caillauda C.M., Via S. 2000. Specialized feeding behavior influence both ecological specialization and assortative mating in sympatric host races of pea aphids. American Naturalist 156: 606-621.

Cichocka E., Ciepiela A., Goszczyński W. 2002. Wpływ zawartości aminokwasów na podatność wybranych odmian bobu na mszycę burakową. [Effect of amino acid contents on acceptance of broad bean cultivars to black bean aphid]. Progress in Plant Protection/Postępy w Ochronie Roślin 42 (2): 662-665.

Goławska S. 2010. Effect of various host-plants on the population growth and development of the pea aphid. Journal of Plant Protection Research 50 (2): 224-228.

Goławska S., Łukasik I., Wójcicka A. 2007. Acyrthosiphon pisum (Harris, 1776) feeding behaviour on various host-plants. Aphids and Other Hemipterous Insects 13: 165-174.

Hodges L.R., McLean D.L. 1969. Correlation of transmission of Bean Yellow Mosaic Virus with salvation activity of Acyrthosiphon pisum Harris (Homoptera: Aphididae). Annals of the Entomological Society of America 62 (6): 1398-1401(4).

Holman J. 2009. Host Plant Catalog of Aphids. Palearctic Region. Springer, 1140 pp.

Kilian L., Nielson M.W. 1971. Differential effects of temperature on the biological activity of four biotypes of the pea aphid. Journal of Economic Entomology 64 (1): 153-155.

Kolasińska K., Wiewióra B. 2002. Wpływ zawartości tanin w nasionach bobiku Vicia faba L. na zdolność kiełkowania, wigor, zdrowotność i plon nasion. Biuletyn Instytutu Hodowli i Aklimatyzacji Roślin 221: 235-240.

Leszczyński B. 1996. Kurs praktyczny w zakresie chemicznych interakcji owad-roślina na przykładzie mszyc (Aphidoidae). Wydawnictwa Uczelniane WSRP w Siedlcach: 16-36.

Montllor C.B. 1991. The influence of plant chemistry an aphids feeding behavior. p. 125-173. In: „Insect-Plant Interactions” (E. Bernays, ed.). CRC Press, London, 438 pp.

Montllor C.B., Tjallingii W.F. 1989. Stylet penetration by two aphid species on susceptible and resistance lettuce. Entomologia Experimentalis et Applicata 52: 103-111.

Mrówczyński M., Wachowiak H., Pruszyński G. 2006. Zagrożenie upraw małoobszarowych przez szkodniki i metody ochrony. [Pest control in minor crops]. Progress in Plant Protection/Postępy w Ochronie Roślin 46 (1): 99-107.

Ropek D., Kulig B. 2009. Podatność odmian bobiku o zróżnicowanej zawartości tanin na szkodniki. [Susceptibility of faba bean cultivars with different tannin content to pests]. Progress in Plant Protection/Postępy w Ochronie Roślin 49 (1): 134-137.

Ropek D., Kulig B. 2011. Wpływ uprawy mieszanki bobiku z owsem nagoziarnistym w systemie ekologicznym na występowanie szkodników. [The effect of field bean-hullness oat mixture in ecological cultivation on the occurrence of pests]. Progress in Plant Protection/Postępy w Ochronie Roślin 51 (3): 1291-1295.

Sądej W., Nietupski M. 2000. Occurrence of pea aphid (Acyrthosiphon pisum Harris) on faba bean and some biotic factors reducing its numbers. Journal of Natural Science 5: 73-82.

Słomka W., Kordan B. 2008. Rozwój mszycy grochowej (Acyrthosiphon pisum Harris) na siewkach wybranych odmian grochu siewnego (Pisum sativum L.). [Development of Acyrthosiphon pisum Harris on selected cultivars of Pisum sativum seedings]. Progress in Plant Protection/Postępy w Ochronie Roślin 48 (3): 970-973.

Słomka W., Kordan B. 2010. Bobowate (Fabaceae) jako siedlisko rozwoju mszycy grochowej (Acyrthosiphon pisum Harris). [Papilionaceae as a habitat for the development of pea aphid (Acyrthosiphon pisum Harris)]. Progress in Plant Protection/Postępy w Ochronie Roślin 50 (4): 1747-1751.

Sohi S.S., Swenson K.G. 1964. Pea aphid biotypes differing in Bean Yellow Mosaic Virus transmission. Entomologia Experimentalis et Applicata 7 (1): 9-14.

Szelegiewicz H. 1968. Katalog fauny Polski. Mszyce. Aphidoidea. PWN, Warszawa, 316 ss.

Węgorek W. 1969. Specjalizacja pokarmowa mszycy grochowej (Acyrthosiphon pisum Harris). Prace Naukowe Instytutu Ochrony Roślin 10 (2): 53-60.

Wójtowska M. 1990. Wpływ różnych czynników na liczebność mszycy grochowianki na różnych roślinach motylkowych. Zeszyty Problemowe Postępów Nauk Rolniczych 392: 161-169. 